$\mathbb{T}$ periodica polytechnica

\author{
Civil Engineering \\ 57/2 (2013) 157 172 \\ doi: 10.3311/PPci.7171 \\ http://periodicapolytechnica.org/ci \\ Creative Commons Attribution (1) \\ RESEARCH ARTICLE
}

\section{Study the prying effect on bolted base-plate connections}

\author{
Levente Katula / Péter Márai
}

Received 2012-08-01, revised 2012-09-10, accepted 2013-04-30

\section{Abstract}

The paper presents the details and results of an experimental study on bolted base-plate joints of industrial type steel building frames. The investigated joints are commonly used in industrial buildings.

The aim of the research was to determine the failure mode and load bearing capacity of the base-plate joints with different base-plate thicknesses and by different anchorage length. In the experimental programme 14 full scale specimens were tested and covered three different end-plate thicknesses. The steel grade of the test specimens was S355, the bolt diameter M20, whereas the bolt grade was 5.6. The tested joint arrangement was the same during the test series, with exception the base-plate thickness $\left(t_{\mathrm{bp}}=16 \sim 20 \sim 24 \mathrm{~mm}\right)$.

The specimens were investigated under pure bending conditions using a four-point-bending arrangement, in which the test specimens were changed. In all tests the typical displacements were measured by inductive transducers under the loads and in the cross-section of the tested joint. The bolt force distribution was registered by special load cells.

The measured data were presented and evaluated by momentbolt-row force and moment-deflection diagrams. From the results the typical failure modes and the joint behaviour were specified and presented. Furthermore the influence of the pretensioning of the bolts on the behaviour of bolted joints and the evolving of the prying effect were analyzed.

\section{Keywords}

bolted base-plate connection $\cdot$ experiment $\cdot$ prying effect

\section{Levente Katula}

Department of Structural Engineering, Budapest University of Technology and Economics, Múegyetem rkp. 3, H-1111 Budapest, Hungary

e-mail:katula@vbt.bme.hu

\section{Péter Márai}

Lindab Building Systems Kft., Derkovits u. 119, H-4400 Nyíregyháza, Hungary

\section{Introduction}

1.1 Background and problem statement

Steel industrial and agricultural halls as well as multi-storey steel buildings, which are widely used today, involve bolted base-plate joints. For steel constructions the bolted base-plate joints are the obvious solution because of the easy installation.

The design of bolted joints, due to their complex behaviour and the wide variety of their arrangement - bolt number and arrangement, plate thickness, joint arrangement, etc. -, is with the current European design standards possible. This offers accurate calculation model - i.e. the component method [1] - that consider the effect of various components of the joint upon its ultimate load-bearing capacity. The resistance, stiffness and ductility of each component of the joint can be calculated and combined to joint resistance. The advantage of such models is that, they are able to reflect the consequences of modification in the joint arrangement during the design process, and therefore give the freedom to optimize the joint arrangement.

\subsection{Previous studies}

Significant theoretical work was done on the field of the component method by Jaspart [2], whom work refined the calculation method. However the standard [1] gives design rules for the calculation of base-plate joints with anchor bolts but there are no rules for other types of fasteners, for example headed studs. Kuhlmann et al. [3] carried out tests to study the effect of different fasteners on the behaviour and load bearing capacity.

Other researchers like Latour \& Rizzano [4] or Fernezelyi \& Viczián [5] fulfilled analytical studies to verify the seismic resistance or the stiffness of base-plate joints respectively.

Although in engineering practice the - geometrical and material - uncertainties can play a role and limit the load carrying capacity [6] the authors in the present paper does not deal with this topic

\subsection{Purpose of the study}

The purpose of the study was to perform experimental and analytical studies on different base-plate thicknesses and by different anchorage length to determine the effect of the anchor- 
age length on the failure mode and on the load bearing capacity. Furthermore the influence of the anchorage length on the prying effect was studied and evaluated.

The investigated arrangements (Figure 1) are summarized in Table 1 In the first column the ID of the specimens are listed, in second, third and fourth the test carried out, in fifth the tested anchorage length $\left(L_{\text {be_test }}\right)$.

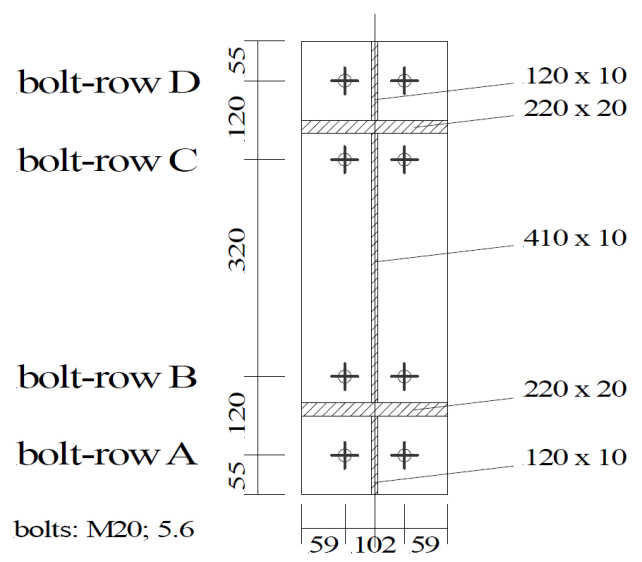

Fig. 1. Detail of the tested base-plate

[1] describes in Table 6.2 a criterion for prying force, if $L_{\mathrm{b}} \leq$ $L_{\mathrm{b}}^{*}$, than prying forces may develop. Were $L_{\mathrm{b}}$ is the anchor bolt elongation length - see Figure 3 and $L_{\mathrm{b}}^{*}=\left(8,8 m^{3} A_{\mathrm{s}}\right) /\left(\Sigma l_{\mathrm{eff}, 1} t_{\mathrm{f}}^{3}\right)$.

Because of the prying effect has a major role in failure Mode 1 and 2 it is important to verify the limit elongation lengths of the bolt within the prying force develop.

Figure 2 explains the possible T-stub failure modes according to [1]. Mode 1 is the complete yielding of the end-plate only, whereas Mode 2 is a combination of bolt failure and plate yielding and Mode 3 belongs to the pure bolt failure.

\subsection{Research strategy}

In the first step an experimental programme was designed and completed, which included three different end-plate thicknesses and covered fourteen specimens as summarized in Table 1 . The experiments were accomplished in the Structural Laboratory of the Budapest University of Technology and Economics. The tests focused on the physical phenomena, which constitute the basis of the analytical study and the further evaluation.

\section{Research programme}

\subsection{Test specimens}

Table 1 shows the tested "effective" $\left(L_{\text {be_test }}\right)$ and the physical length $\left(L_{\text {phys }}\right)$ of the anchor bolts. The total length of the anchoring bolt in the design model, according to [1], is interpreted as follows:

$$
L_{\mathrm{b}}=0.5 b_{\text {head }}+t_{\text {washer }}+t_{\mathrm{bp}}+t_{\text {mortar }}+L_{\mathrm{be}}
$$

where

$b_{\text {head }}$ height of the bolt head

$t_{\text {washer }}$ thickness of the washer $t_{\mathrm{bp}} \quad$ thickness of the base-plate

$t_{\text {mortar }}$ thickness of the mortar

$L_{\text {be }} \quad$ effective length of the anchor bolt, which is approximately $L_{\mathrm{be}}=8 \cdot d$; where $d$ is the nominal bolt diameter in $\mathrm{mm}$.

Figure 3 illustrates the difference between the physical $\left(L_{\text {phys }}\right)$ and the total length $\left(L_{\mathrm{b}}\right)$ of the anchor bolt. Figure 4 shows, as an example, the test specimen BP20 $\left(t_{\mathrm{bp}}=20 \mathrm{~mm}\right)$ with the geometrical dimensions. The following dimensions were identical for all test specimens:

- total length of the specimen $1.480 \mathrm{~mm}$;

- cross-section of the specimen;

- width and height of the end-plates $670 \times 220 \mathrm{~mm}$ and

- the steel grade of the test specimens, S355.

All bolts were homogeneous preloaded, as far as possible. During the preloading process the bolt forces, i.e. preload levels, were measured by the applied load cells.

\subsection{Test arrangement}

A four-point-bending arrangement was used, as shown in Figure 5. The used static system was a simply supported beam with two concentrated load, acting in the vertical axis, symmetrically $800 \mathrm{~mm}$ from the supports. The tested specimens were erected to the fixed girder. The fixed girder served the economy of the fabrication of the specimens.

The two concentrated loads were applied by hydraulic jacks with capacities of $1.000 \mathrm{kN}$.

\subsection{Measuring system}

During the tests representative displacements were measured by inductive transducers placed under the loads and in the crosssection of the investigated joint. The distribution of the bolt forces was registered by load cells in each bolt. The measured data were collected in each second, by two data collection systems.

Figure 6 shows the measuring points where the inductive transducers and the load cells were placed.

\section{Test results}

The collected data were prepared and presented by the following diagrams: moment vs. bolt-row force diagrams and loaddisplacements diagrams. In the following the results for specimen BP16 $\left(t_{\mathrm{bp}}=16 \mathrm{~mm}\right)$ are presented.

Because of different pre-tensioning levels of the bolts the presented bolt-force curves have slightly different starting points.

\subsection{Specimens BP16_0, BP16_1, BP16_2 and BP16_3}

Specimen BP16_0, with practically no anchor length, served as reference test. The bolt force distribution and the load bearing 
Tab. 1. Details of the investigated joints

\begin{tabular}{|c|c|c|c|c|c|}
\hline \multirow[t]{2}{*}{ ID of the test } & \multicolumn{3}{|c|}{ base-plate type } & \multirow{2}{*}{$\begin{array}{c}\text { tested "effective" } \\
\text { length of the anchor } \\
\text { bolt } \\
L_{\text {be_test }}[\mathrm{mm}]\end{array}$} & \multirow{2}{*}{$\begin{array}{c}\text { physical length of the } \\
\text { anchor bolt } \\
L_{\text {phys }}[\mathrm{mm}]\end{array}$} \\
\hline & $\mathrm{BP} 16\left[t_{\mathrm{bp}}=16 \mathrm{~mm}\right]$ & $\mathrm{BP} 20\left[t_{\mathrm{bp}}=20 \mathrm{~mm}\right]$ & $\mathrm{BP} 24\left[t_{\mathrm{bp}}=24 \mathrm{~mm}\right]$ & & \\
\hline $\mathrm{BPt}_{\mathrm{bp} \_} 0$ & $\sqrt{ }$ & $\sqrt{ }$ & $\sqrt{ }$ & $0(=0 \cdot d)$ & 190 \\
\hline $\mathrm{BPt}_{\mathrm{bp} \_} 1$ & $\sqrt{ }$ & $\sqrt{ }$ & - & $160(=8 \cdot d)$ & 350 \\
\hline $\mathrm{BPt}_{\mathrm{bp} \_} 2$ & $\sqrt{*}$ & - & - & $240(=12 \cdot d)$ & 430 \\
\hline $\mathrm{BPt}_{\mathrm{bp} \_3}$ & $\sqrt{ }$ & - & - & $320(=16 \cdot d)$ & 510 \\
\hline $\mathrm{BPt}_{\mathrm{bp} \_} 4$ & $\sqrt{ }$ & $\sqrt{ }$ & $\sqrt{ }$ & $400(=20 \cdot d)$ & 590 \\
\hline $\mathrm{BPt}_{\mathrm{bp} \_5}$ & $\sqrt{ }$ & - & - & $480(=24 \cdot d)$ & 680 \\
\hline $\mathrm{BPt}_{\mathrm{bp} \_6}$ & $\sqrt{ }$ & - & - & $600(=30 \cdot d)$ & 790 \\
\hline $\mathrm{BPt}_{\mathrm{bp} \_} 7$ & $\sqrt{ }$ & - & $\sqrt{ }$ & $800(=40 \cdot d)$ & 990 \\
\hline
\end{tabular}

${ }^{*}$ Because of delivery problems for specimen BP16_2 were in bolt-row $\mathrm{C}$ a bolts with an effective anchorage length $0 \cdot d$ used.

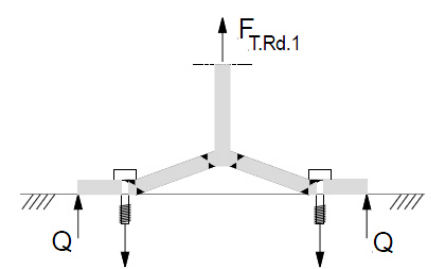

Mode 1

complete yielding of the flange bolt failure with yielding of the flange

prying force (Q) may develop prying force (Q) may develop

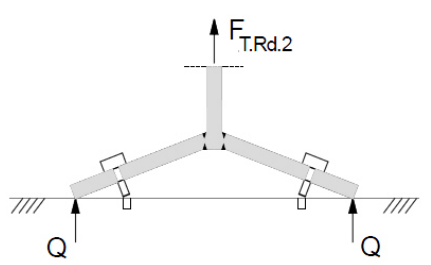

Mode 2

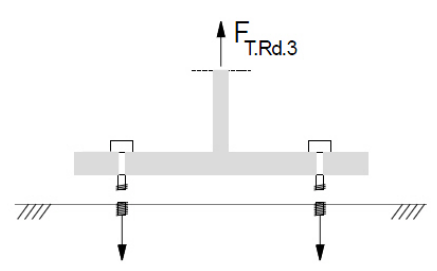

Mode 3

bolt failure

no prying force

Fig. 2. T-stub failure modes according to Eurocode 3

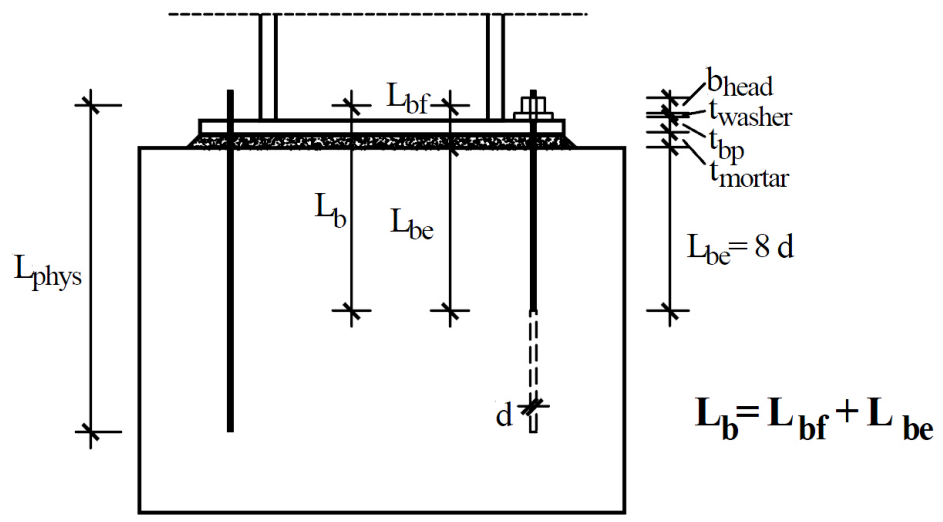

Fig. 3. The length of the anchor bolt

Tab. 2. Sum of pre-tension forces of the bolt-rows A and B

\begin{tabular}{ccccccccc}
\hline specimen ID & BP16_0 & BP16_1 & BP16_2 & BP16_3 & BP16_4 & BP16_5 & BP16_6 & BP16_7 \\
\hline$L_{\text {be_test }[\mathrm{mm}]}$ & $0(0 \cdot d)$ & $160(8 \cdot d)$ & $240(12 \cdot d)$ & $320(16 \cdot d)$ & $400(20 \cdot d)$ & $480(24 \cdot d)$ & $600(30 \cdot d)$ & $800(40 \cdot d)$ \\
\hline sum of the pre-tension forces $[\mathrm{kN}]$ & 95 & 93 & 100 & 101 & 95 & 98 & 95 & 101 \\
\hline
\end{tabular}




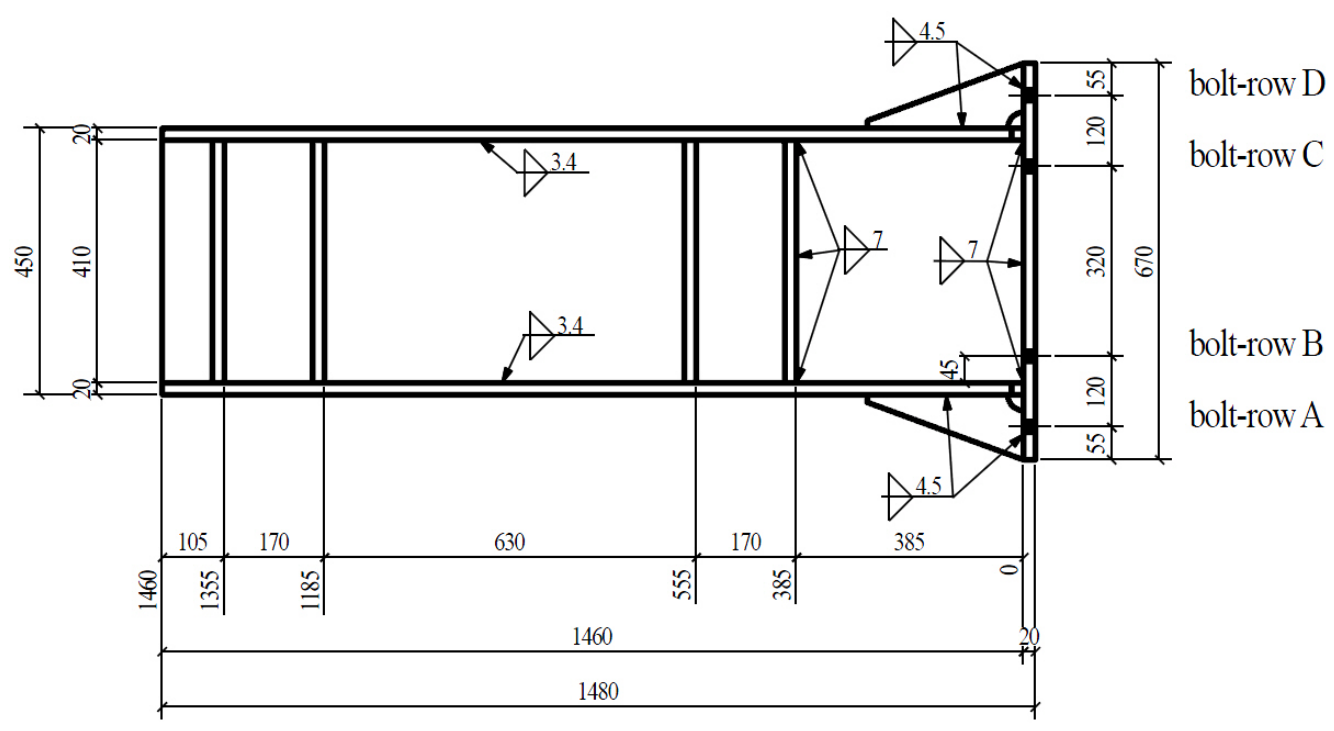

Fig. 4. The test specimen BP20

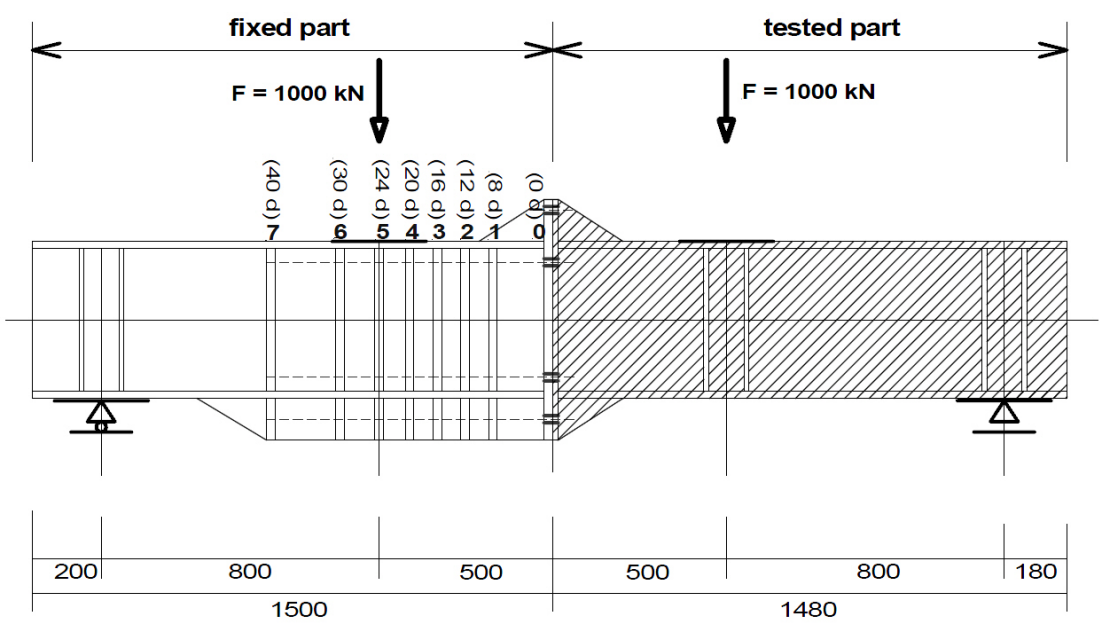

Fig. 5. Test arrangement

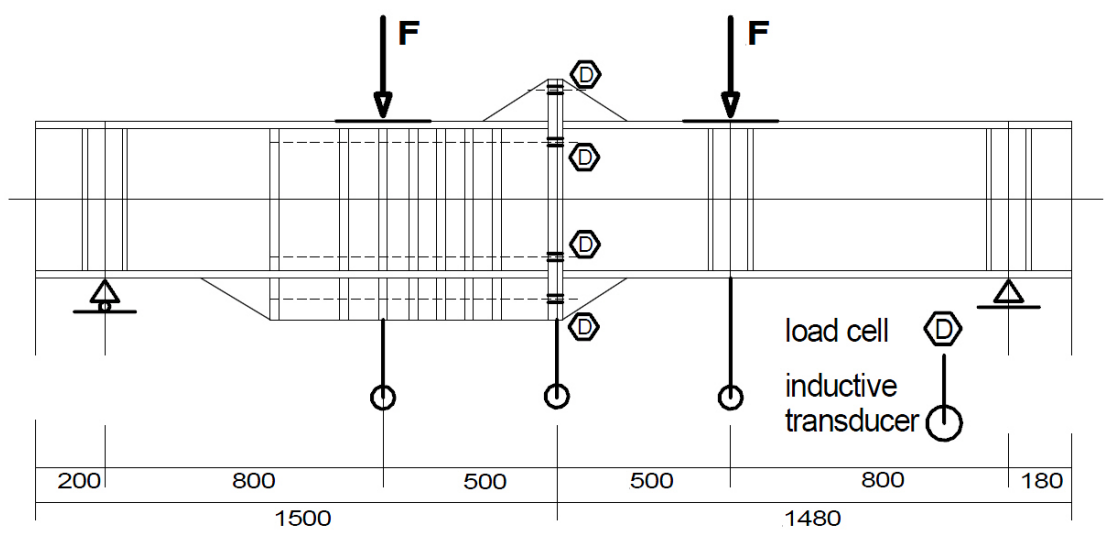

Fig. 6. Locations of transducers and load cells 
capacity of the joint were calculated by a beam-to-beam joint model.

The moment vs. bolt-row force diagram in Figure 7 shows how the force increment changes in the bolt-rows. The tendency on the measuring points belong to bolt-row A and B on the diagram show a definite change at the load level of $60 \mathrm{kNm}$ approximately. After this point a higher slope in the bolt force diagrams to see. This can be explained with the plate deformations and the evolved failure mode. The calculated and observed failure mode of the joint was mixed plate and bolt failure (Mode 2) in all tension bolt-rows. At lower load level the yield lines taking shape in the end-plate both sides of the web. After evolving the plastic deformations in the plate, the edges of the plates closing and the prying effect appearing. In consequence of this effect the diagrams show higher slope until $160 \mathrm{kNm}$ load level approximately. At this load level the prying effect seems to be stopped. Because of the bolt elongations the plate edges have no contacting more in the height of bolt-row A and B. Therefore the slope of the curves falling down and show the same slope as at the beginning of the test.

The same tendency can be observed by bolt-row C. Bolt-row $\mathrm{C}$ starts to work, after this bolt-row become in the tension zone, at the load level of $140 \mathrm{kNm}$. At $210 \mathrm{kNm}$ load approximately the bolt force in row $\mathrm{C}$ increasing in higher manner, which has the same reason as by bolt-rows $\mathrm{A}$ and $\mathrm{B}$ at load level of $60 \mathrm{kNm}$.

The following diagrams show the same observations for specimen BP16_1, BP16_2, and BP16_3. Figures 8-10 show the moment vs. bolt-row force diagrams respectively.

The longer the used bolts, the higher the elongations on the same load level. It means the prying effect should stop at lower load level if the elongation lengths of the bolts are longer. This phenomenon was slightly disturbed due to the different pretensioning level in the tests. The bolts were preloaded in each test. The goal was to get a homogeneous pre-tensioning level in the bolts, but the achieved pre-tensioning showed minimal differences to each other. This can be bringing back to the following effects: certain friction differences of the bolts (imperfect form, different coating thickness of the bolts); erection imperfections; little inhomogeneous stiffness distribution.

In Table 2 the sum of the pre-tension forces are presented of the bolt-rows A and B. The Table shows that by specimens BP16_2, BP16_3 and BP16_7 the pre-tension level is slightly higher than by the other specimens. The effect of these differences is to see in the following moment vs. bolt-row force diagrams. Instead of continuous decreasing of the load level at which the prying effect stops in bolt-row A and B due to using longer bolts, the higher pre-tension level can enhance it.

Figure 11 shows the moment-displacement diagrams of specimens BP16_0 - BP16_3. Until $150 \mathrm{kNm}$ load the specimens show linear behaviour and on the same load level approximately become the bolt-row $\mathrm{C}$ tension.

The deflection curves BP16_1, BP16_2 and BP16_3 show practical the same behaviour which observation is inconsistent with the theoretical consideration. This phenomenon can explained with the higher pre-tension level of the bolts by specimens BP16_2, BP16_3. Due to higher pre-tensioning changing the joint behaviour i.e. the stiffness of the joint is growing.

\subsection{Specimens BP16_4, BP16_5, BP16_6 and BP16_7}

The following diagrams - in Figures $12-15$ - show the test results for specimens with anchor length equal or higher than $20 \cdot d(400 \mathrm{~mm})$.

The diagrams in Figures 12-15 show similar joint behaviour. If the bolt length equal or higher than $20 \cdot d$ then the stiffness of the bolts is not enough to yield the plate, so breaks the plate the bolts in bolt-rows A and B without significant plate deformations.

Henceforth in bolt-row $\mathrm{C}$ the prying effect was observed. This can be explained with the bolt arrangement, because the boltrow $\mathrm{C}$ was placed more close to the centre of compression. Therefore in bolts belongs to bolt-row $\mathrm{C}$ the bending effect was significant, which reduces the effective elongation length. Thus shows the same bolt in bolt-row $\mathrm{C}$ higher stiffness.

Figure 16 presents the moment-displacement diagrams of specimens BP16_4 - BP16_7. In spite of the used longer bolts shows the moment-displacement curve of the specimen BP16_7 smaller deflections than the diagrams belongs to tests BP16_5 and BP16_6. Like Table 2 showed the pre-tension level in specimen BP16_7 was higher, which caused this more rigid behaviour.

The displacements curves of specimens BP16_4, BP16_5 and BP16_6 show the expected sequence except after the slip at $230 \mathrm{kNm}$ load level approximately. The test specimen BP16_5 slipped on the pinned support which caused the demonstrated higher displacements in comparison to specimen BP16_6.

\subsection{Specimens BP20_0, BP20_1 and BP20_4}

The diagrams in Figures 17- 19 present the moment vs. boltrow force relationships for test-specimens with plate thickness of $20 \mathrm{~mm}$.

The diagrams show for bolt-rows A and B linear behaviour similarly. In all tests become the bolt-row $\mathrm{C}$ tension at approximately $180 \mathrm{kNm}$ load level. After this point a higher slope in the bolt force diagrams to see, this is whit the evolving prying effect to explain. At about $270 \mathrm{kNm}$ load level seems the prying effect to stop - see in Figures 18 and 19 - because the bolt elongation makes the withdrawal of the plate edges possible.

Table 3 summarizes the sum of the pre-tension forces of the bolt-rows A and B. The Table shows the longer the bolts are the lower the level of the pre-tension is. 


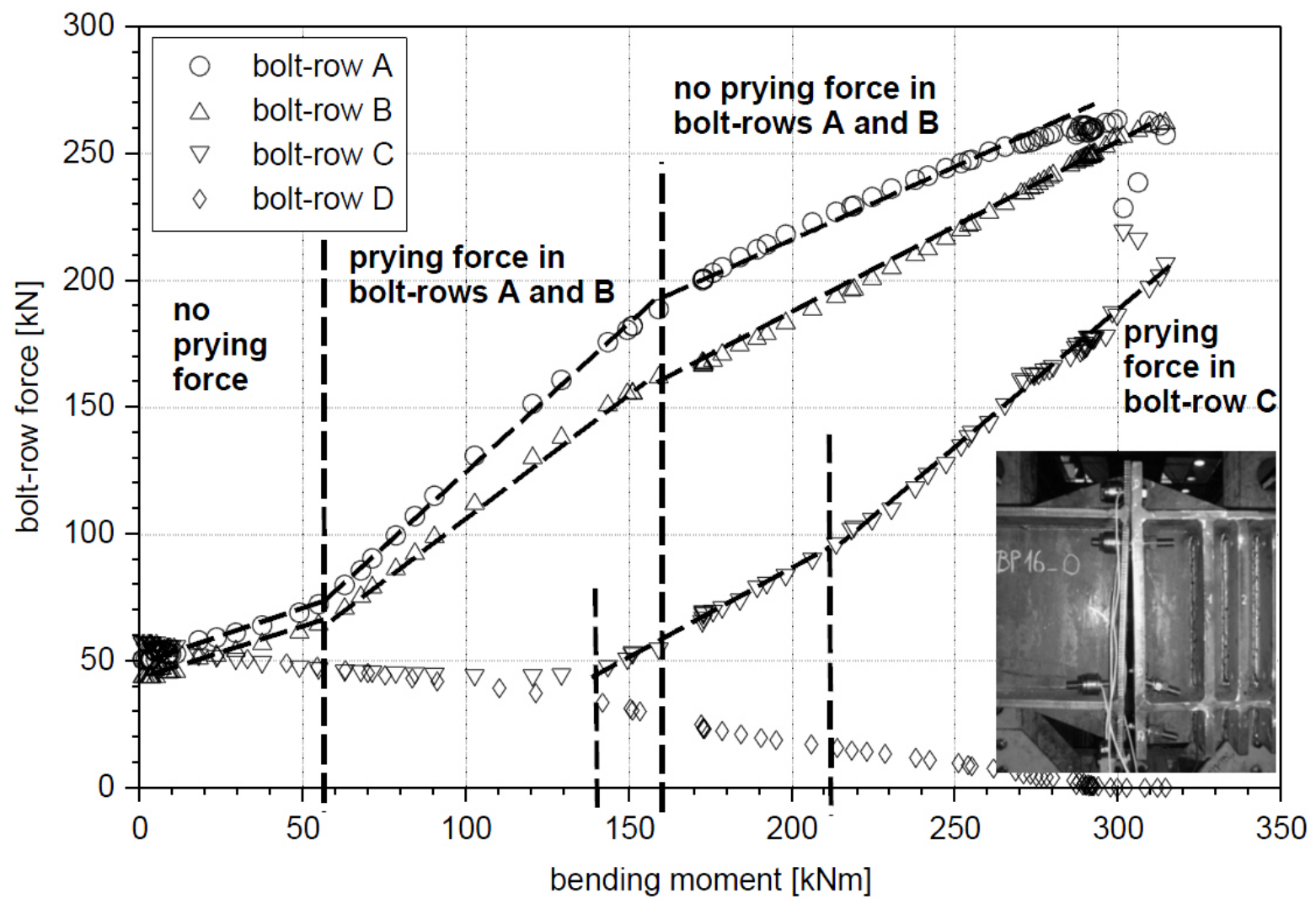

Fig. 7. Moment vs. bolt-row force diagrams $\left(\right.$ BP16_ $\left.0, L_{\mathrm{test}, 0 \mathrm{~d}}=0 \mathrm{~mm}\right)$

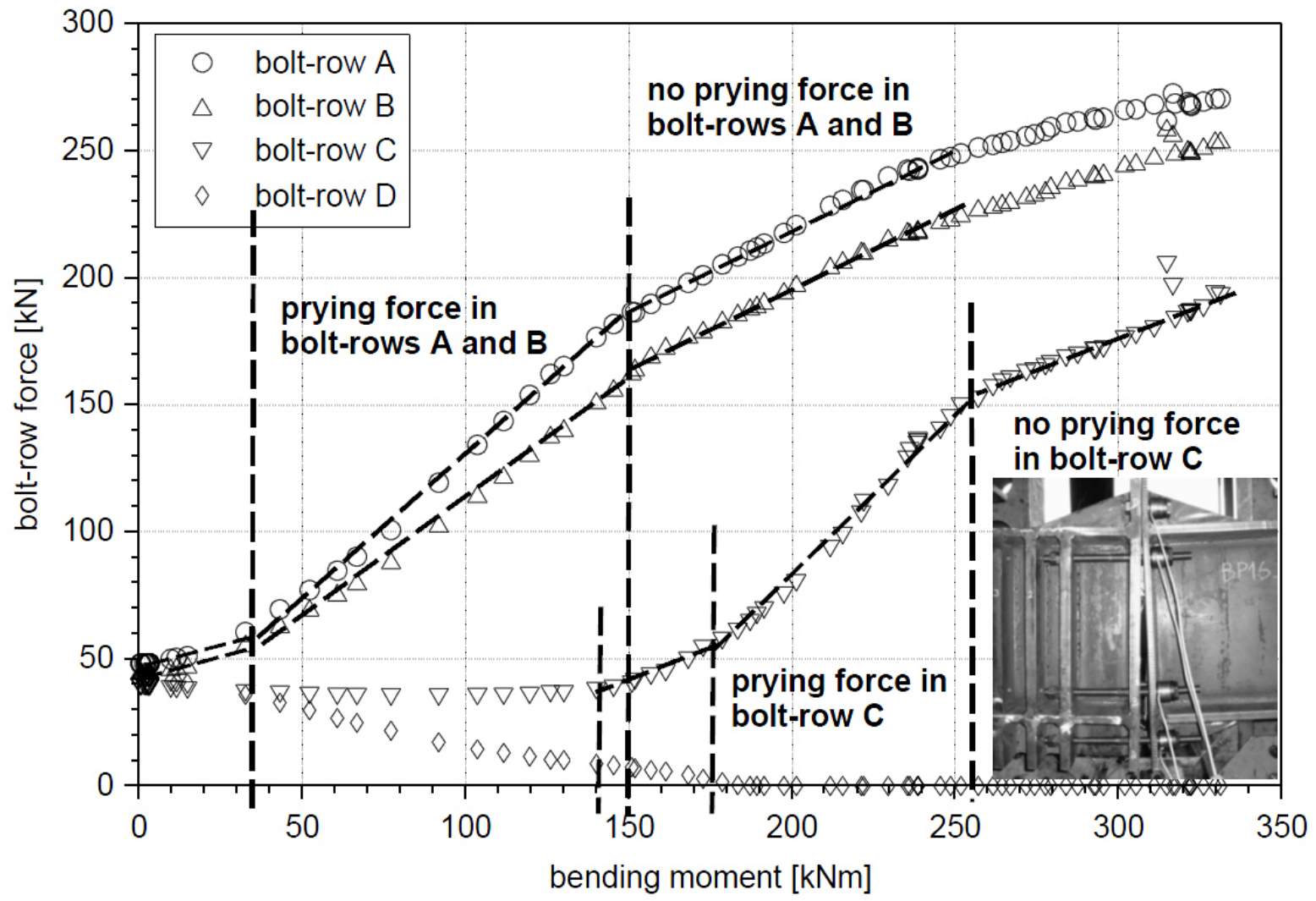

Fig. 8. Moment vs. bolt-row force diagrams $\left(\right.$ BP16_1, $\left.L_{\text {test }, 8 \mathrm{~d}}=160 \mathrm{~mm}\right)$ 


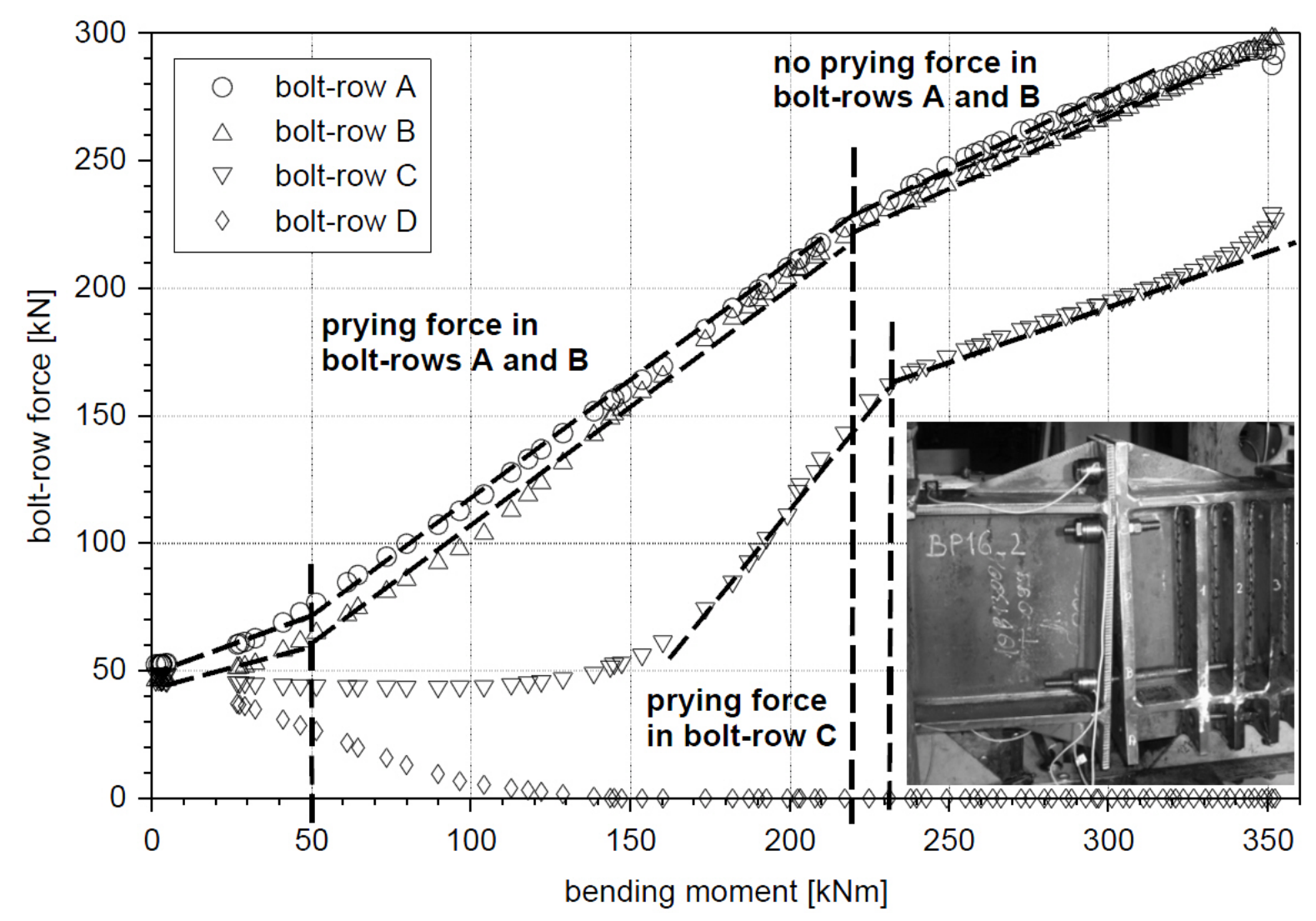

Fig. 9. Moment vs. bolt-row force diagrams (BP16_2, $L_{\text {test } 12 \mathrm{~d}}=240 \mathrm{~mm}$ )

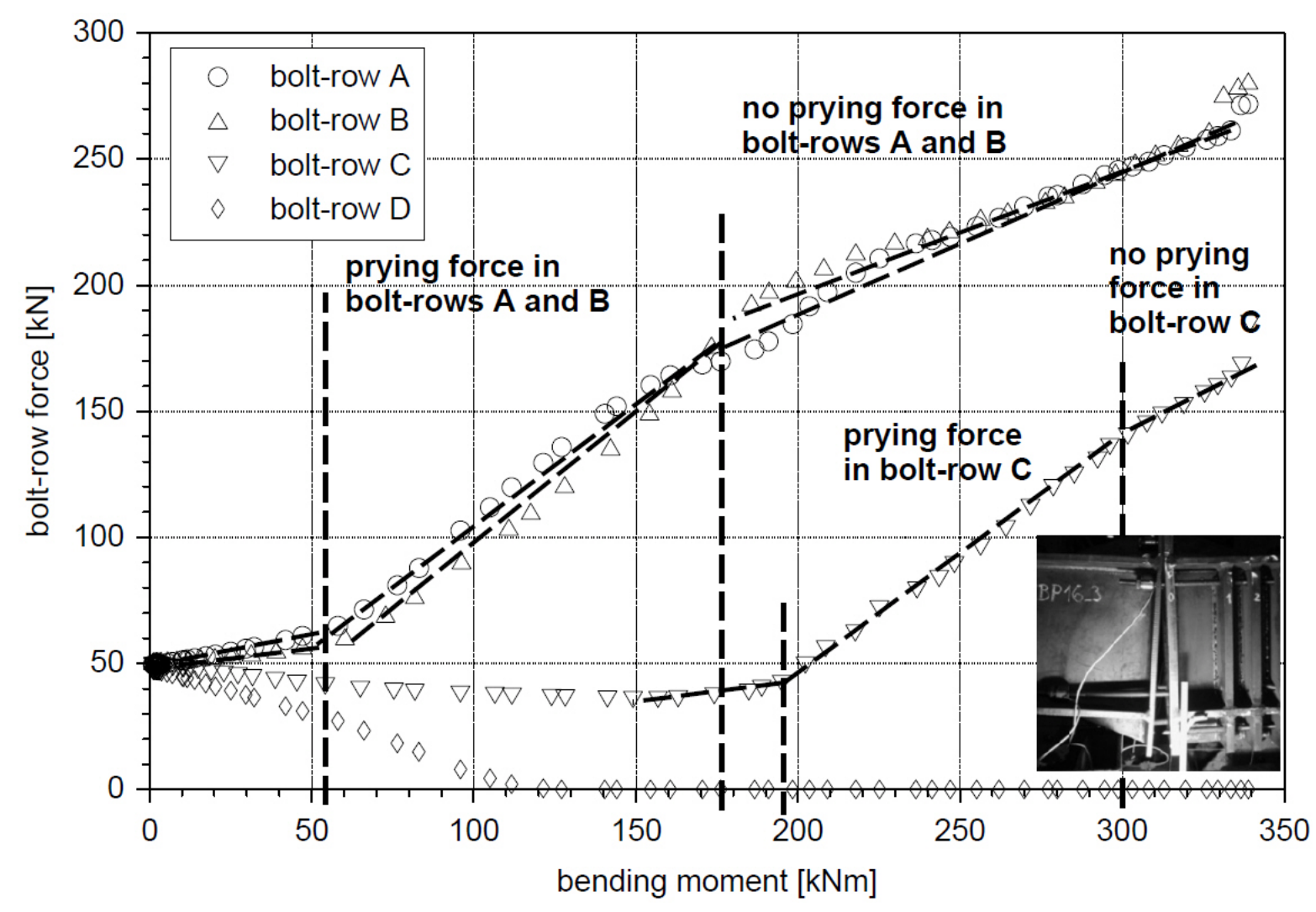

Fig. 10. Moment vs. bolt-row force diagrams (BP16_3, $\left.L_{\text {test } 16 \mathrm{~d}}=320 \mathrm{~mm}\right)$ 


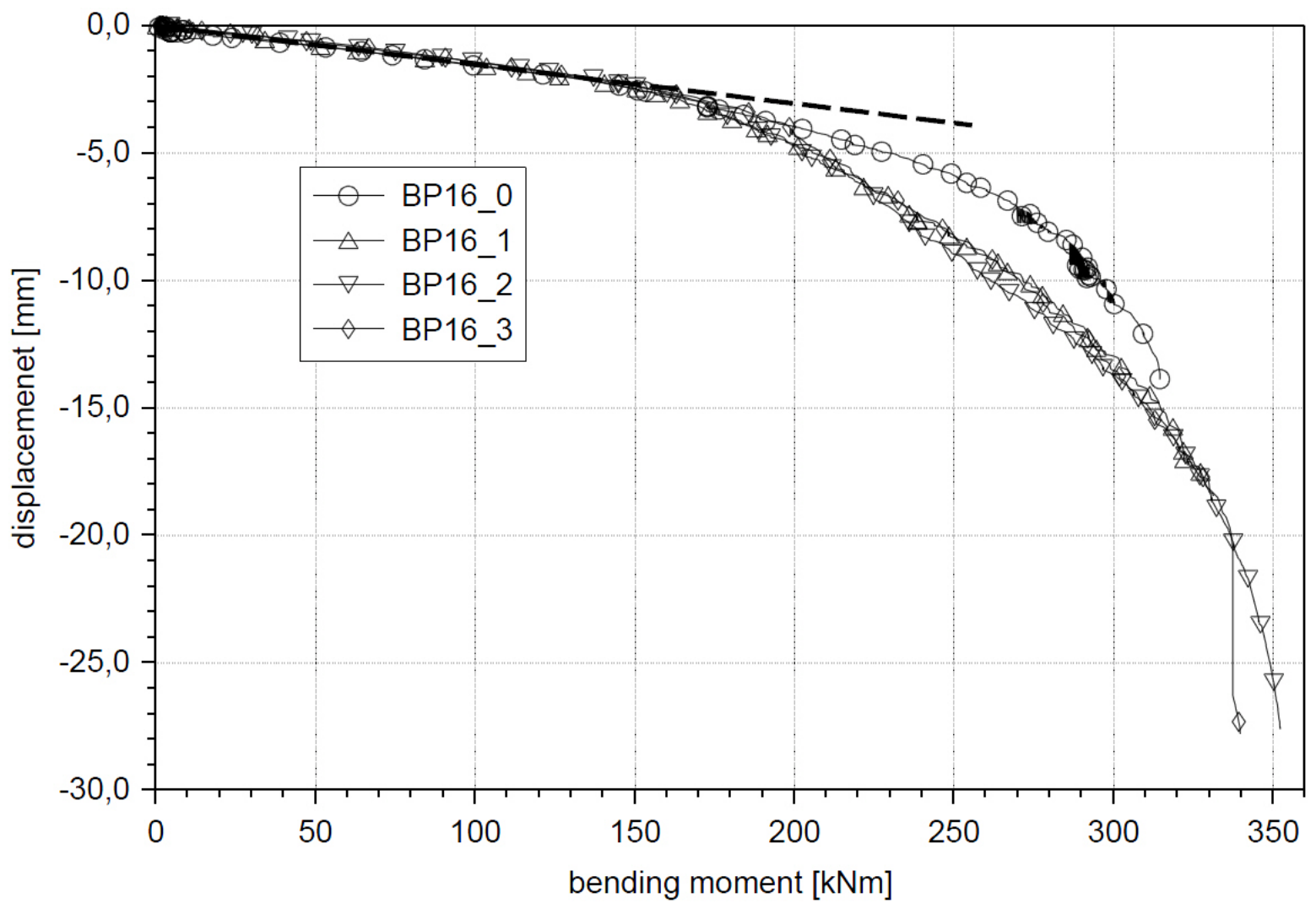

Fig. 11. Moment-displacement diagrams of specimens BP16_0 - BP16_3

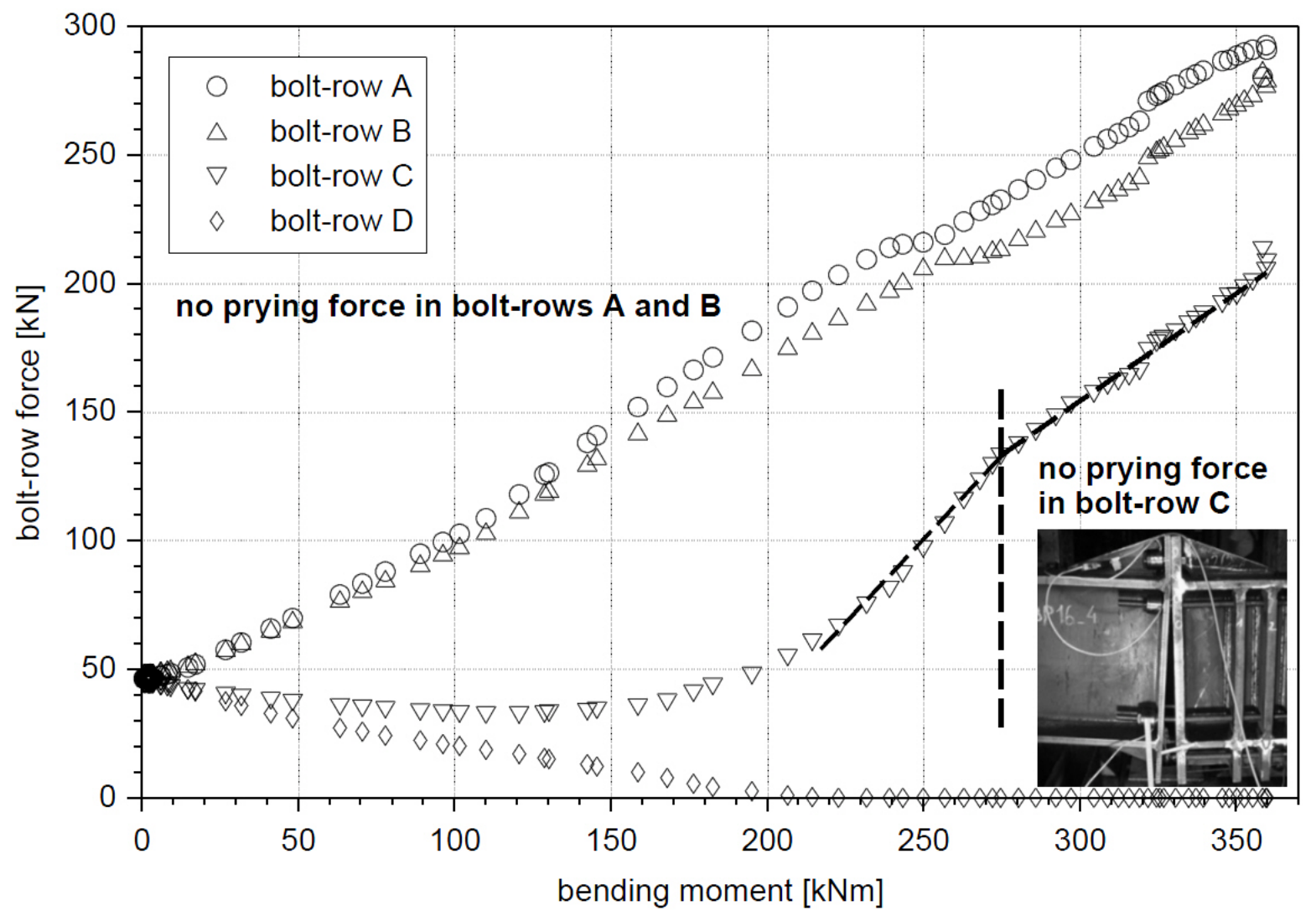

Fig. 12. Moment vs. bolt-row force diagrams $\left(\right.$ BP16_4, $L_{\text {test }, 20 \mathrm{~d}}=400 \mathrm{~mm}$ ) 


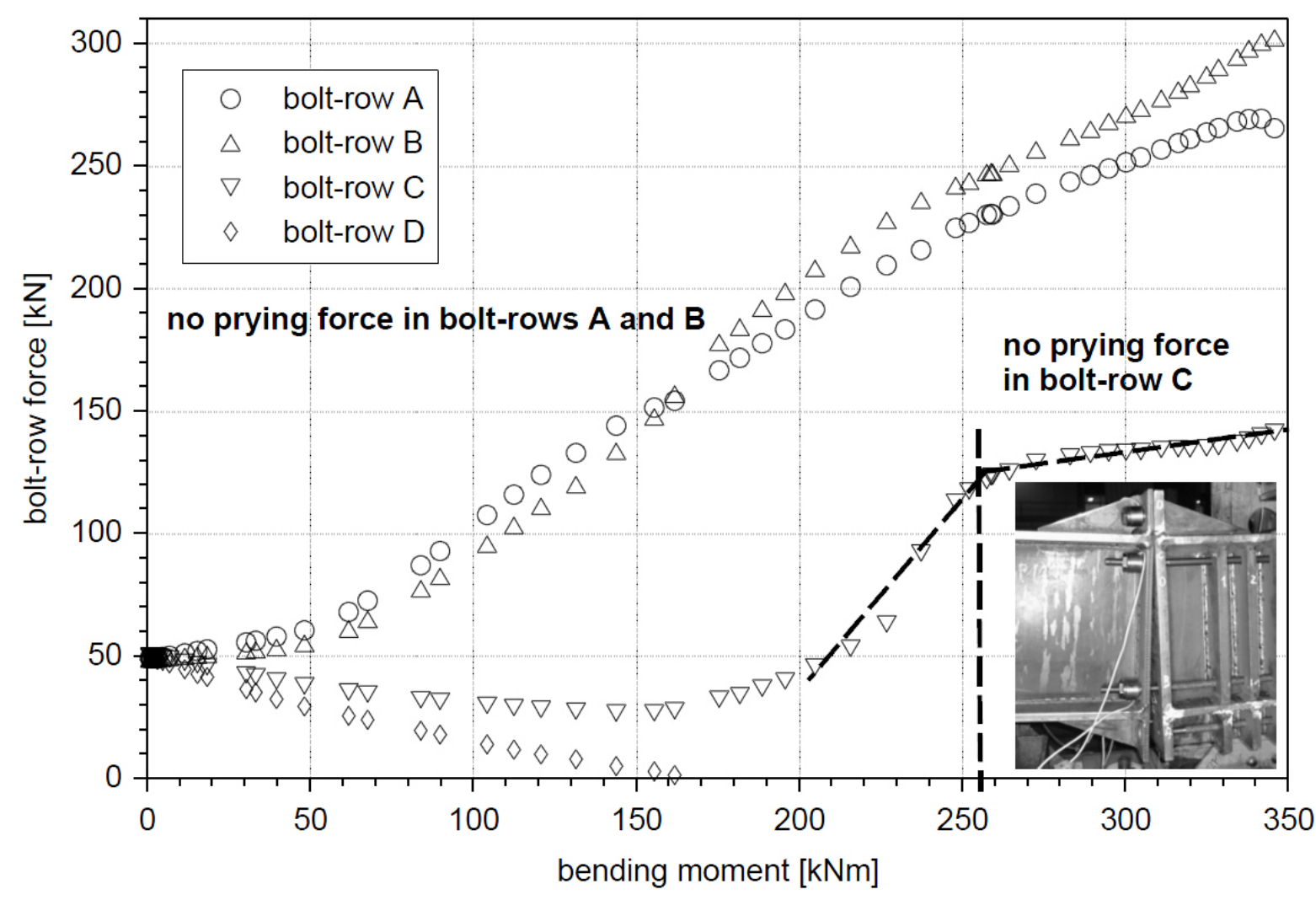

Fig. 13. Moment vs. bolt-row force diagrams $\left(\right.$ BP16_5, $\left.L_{\text {test }, 24 \mathrm{~d}}=480 \mathrm{~mm}\right)$

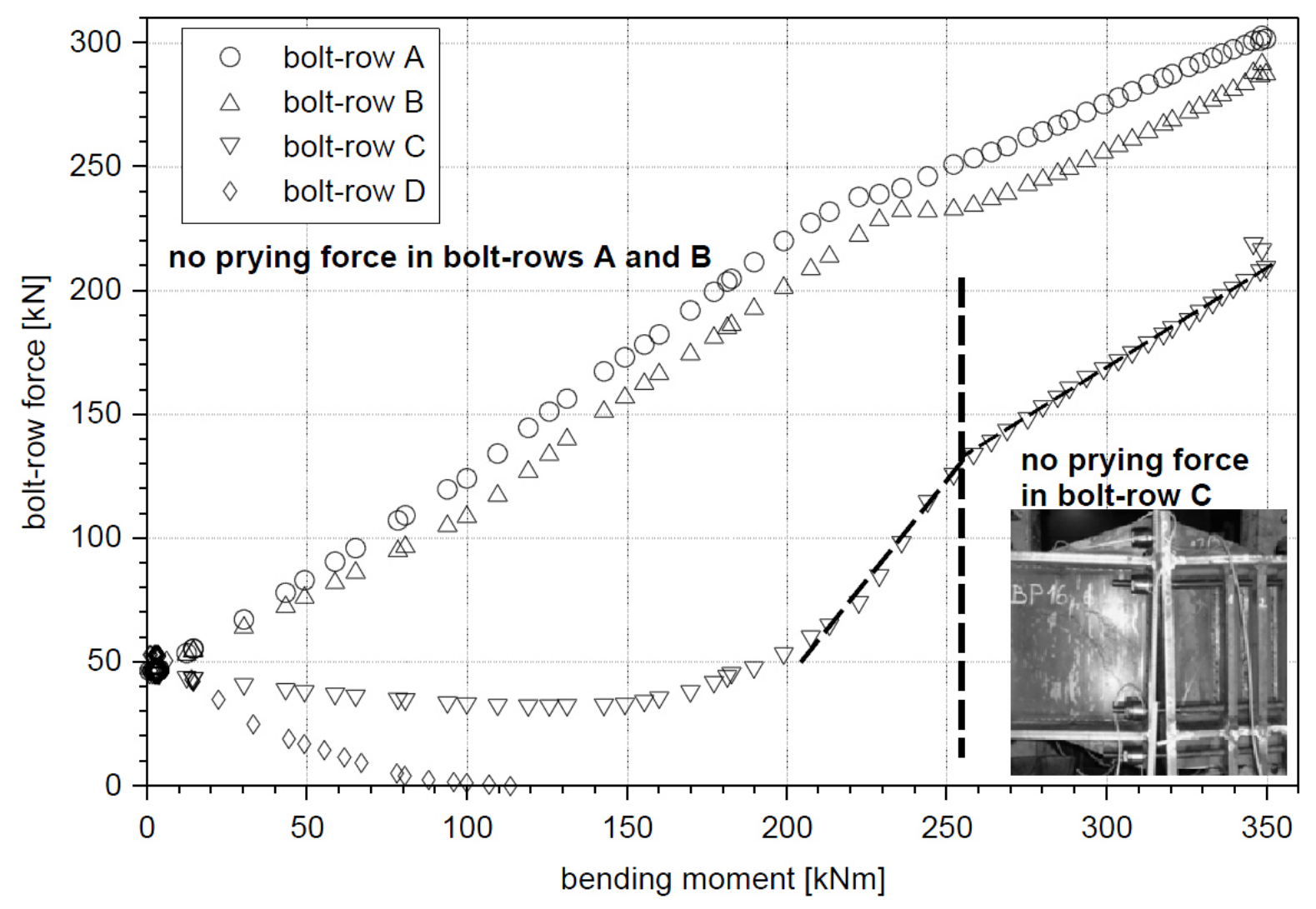

Fig. 14. Moment vs. bolt-row force diagrams $\left(\right.$ BP16_6, $\left.L_{\text {test } 30 \mathrm{~d}}=600 \mathrm{~mm}\right)$ 


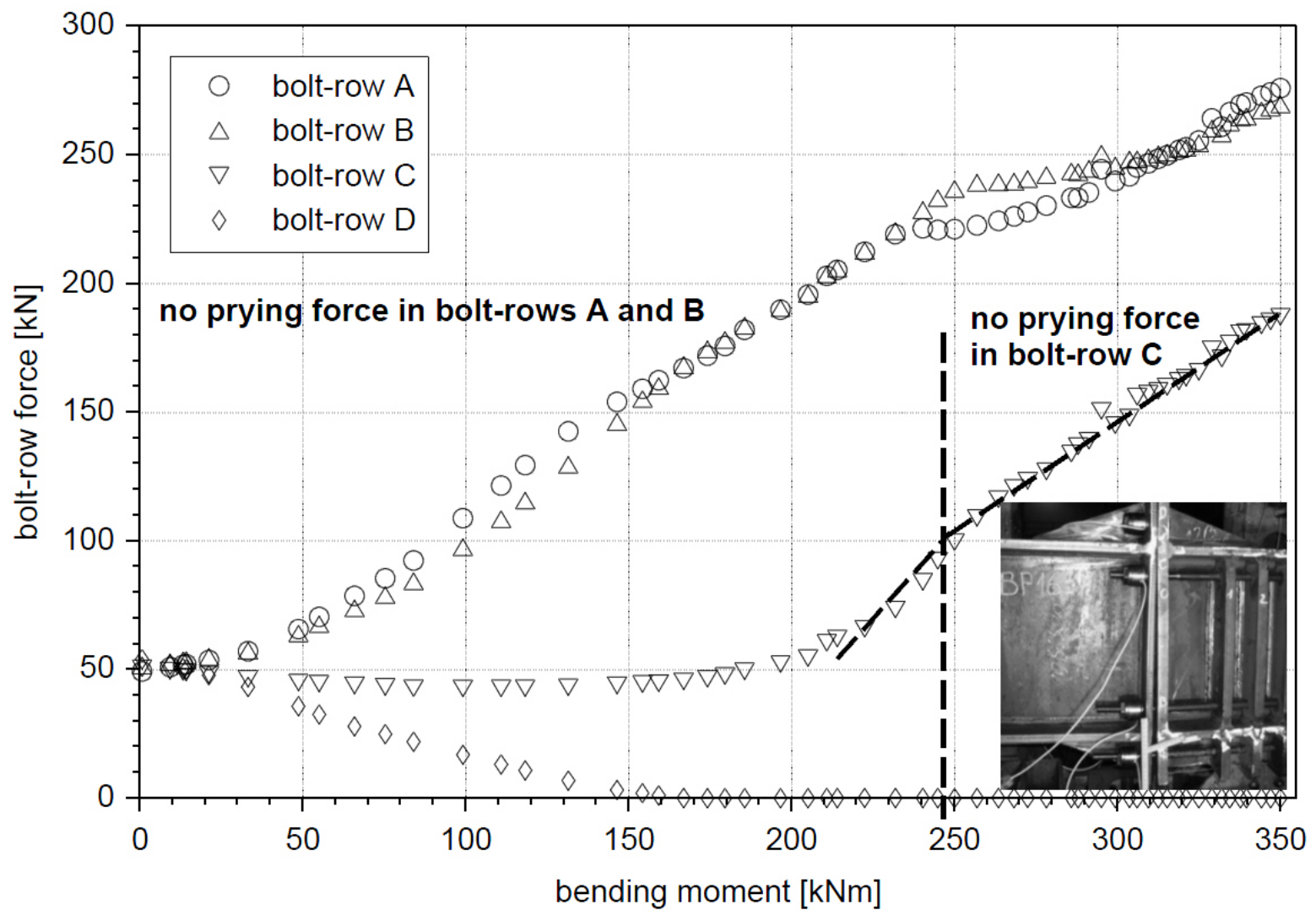

Fig. 15. Moment vs. bolt-row force diagrams (BP16_7, $L_{\text {test } 40 \mathrm{~d}}=800 \mathrm{~mm}$ )

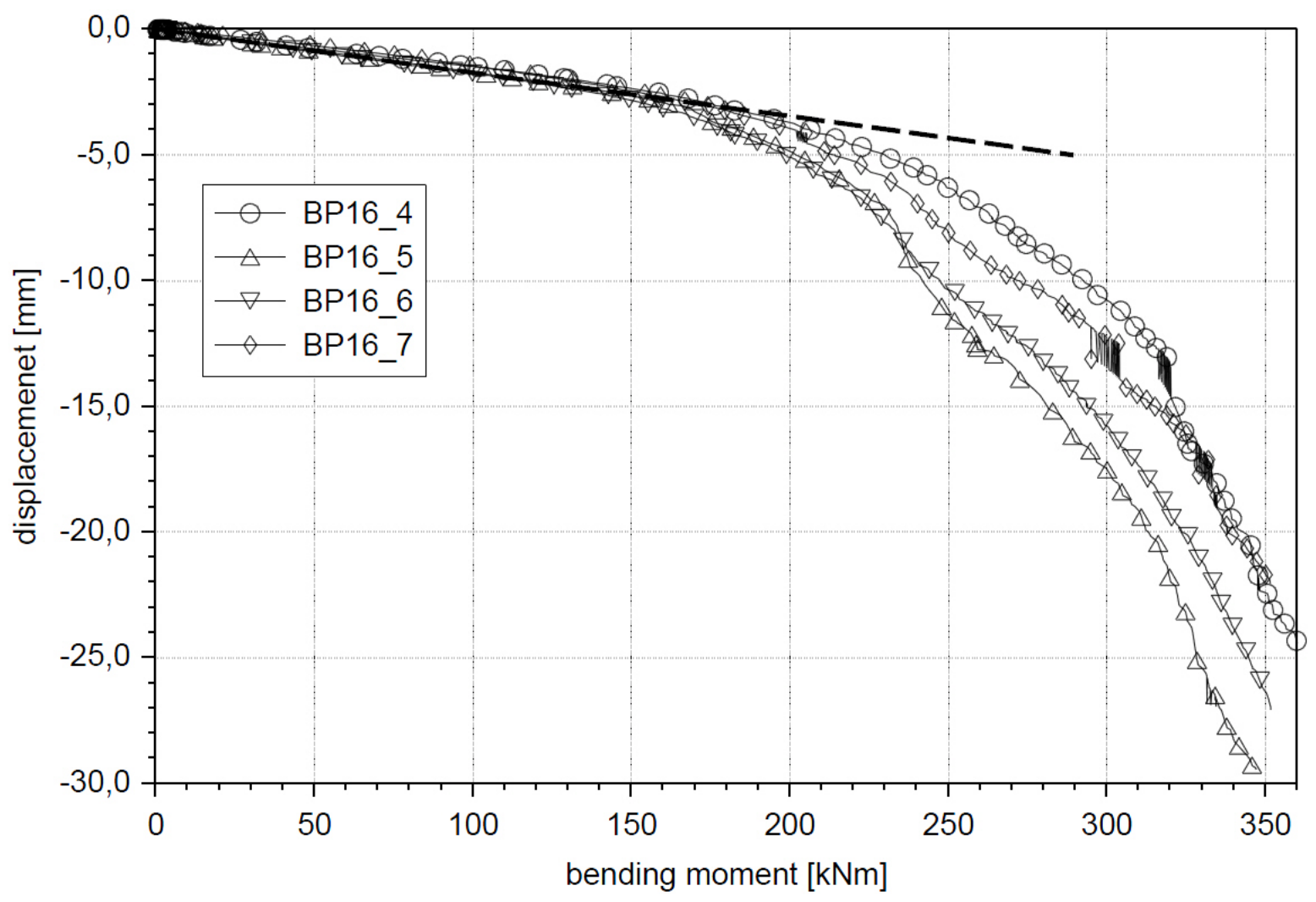

Fig. 16. Moment-displacement diagrams of specimens BP16_4-BP16_7 


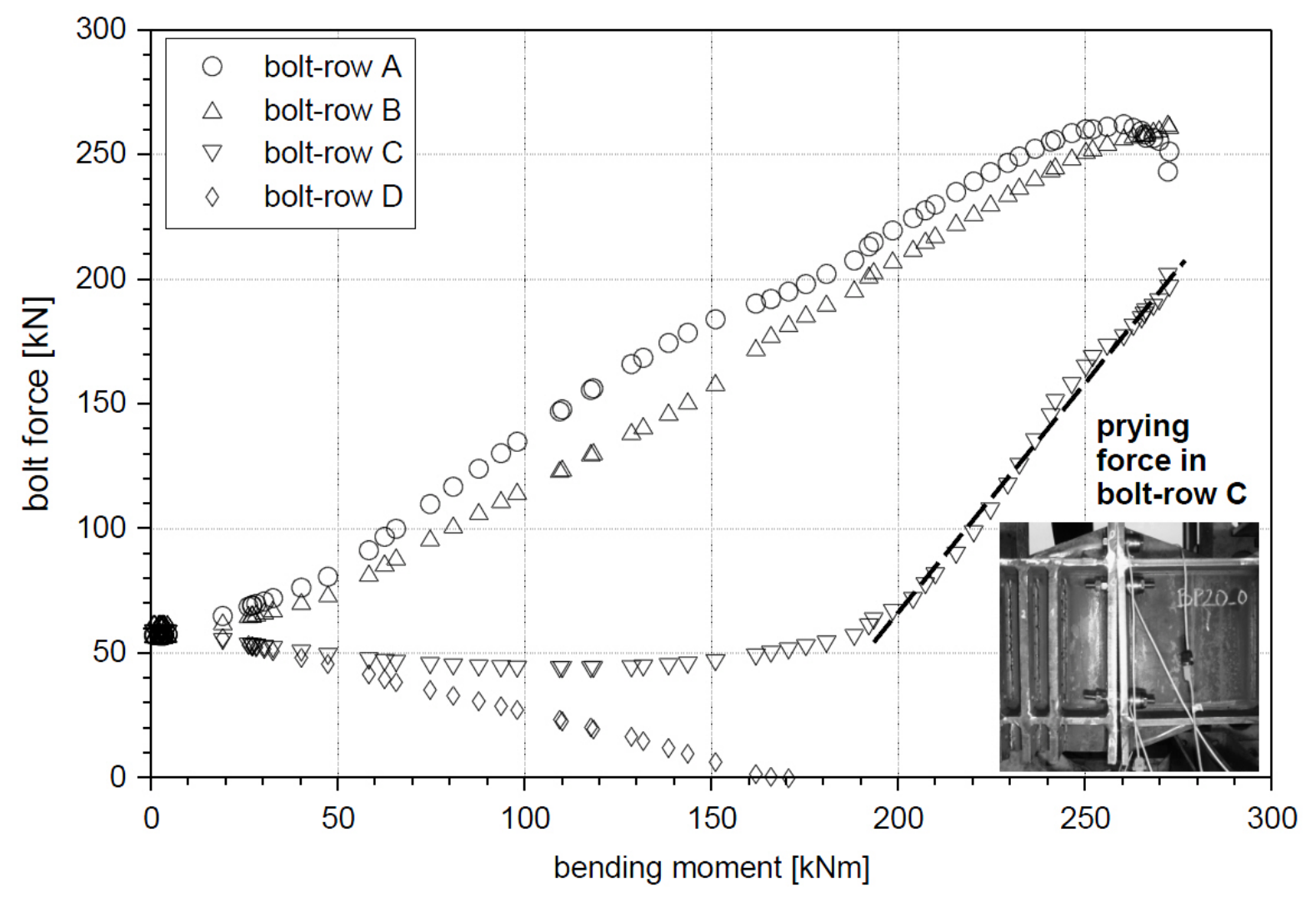

Fig. 17. Moment vs. bolt-row force diagrams BP20_0, $L_{\text {test }, 0 \mathrm{~d}}=0 \mathrm{~mm}$

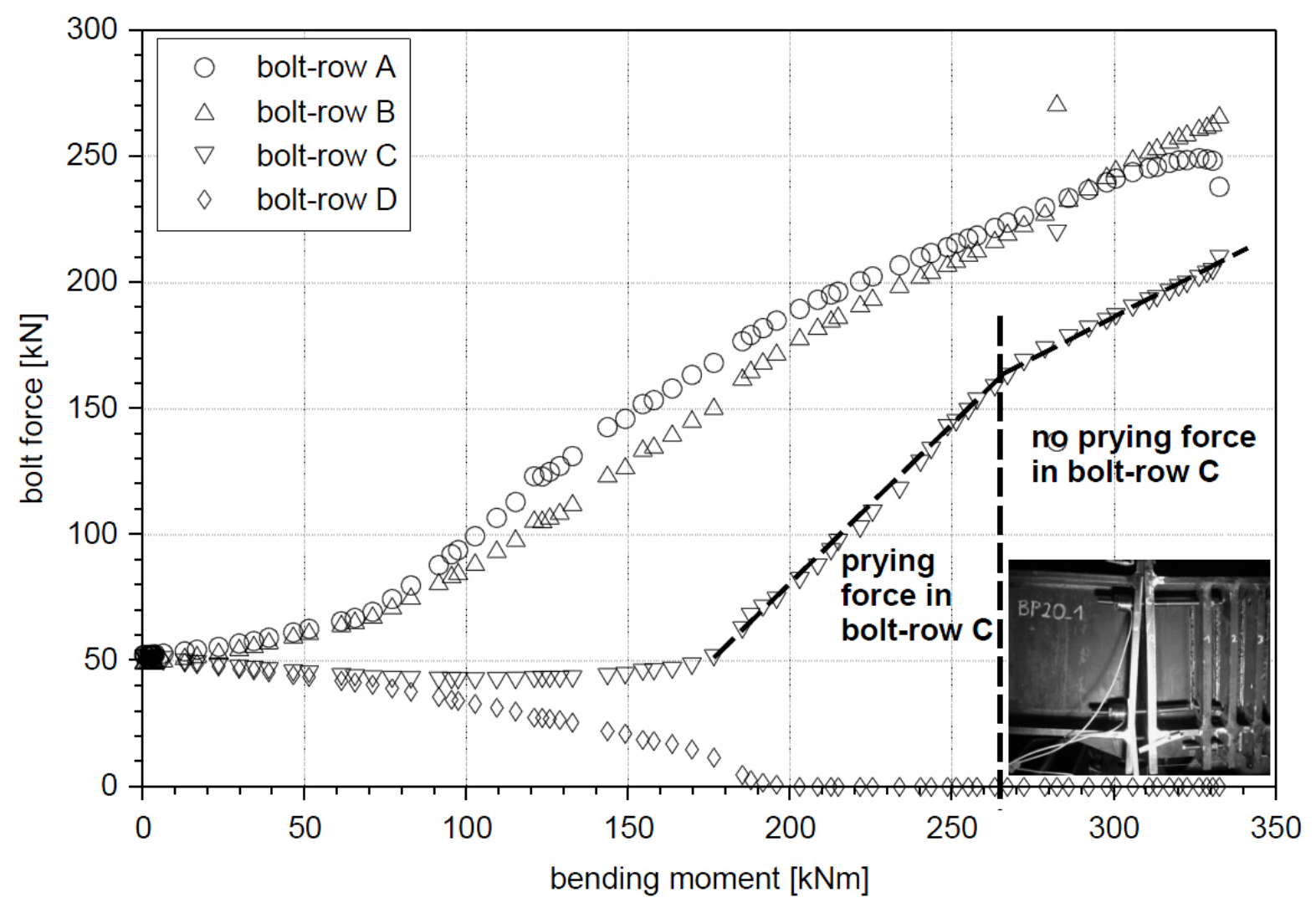

Fig. 18. Moment vs. bolt-row force diagrams $\left(\right.$ BP20_1, $\left.L_{\text {test }, 8 \mathrm{~d}}=160 \mathrm{~mm}\right)$ 
Figure 20 shows the moment-displacement diagrams of specimens BP20_0, BP20_1 and BP20_4. The calculated and observed failure mode was the same - bolt failure - which show the diagrams with the similar behaviour until about $240 \mathrm{kNm}$ load level.

The displacement diagrams demonstrate the higher the anchorage lengths the higher the achieved load bearing capacity. This finding is with the observed behaviour explained. In all tests was the failure mode bolt failure in bolt-row A. But the higher anchorage length is used the higher the bolt elongations are. The higher bolt elongations in bolt-row B and $\mathrm{C}$ allowed the decreasing the stresses from bending in bolt-row A and helped in force the redistribution between the bolt-rows too.

\subsection{Specimens BP24_0, BP24_4 and BP24_7}

The diagrams in Figures $21-23$ show the moment vs. boltrow force relationships for the test-specimens with plate thickness of $24 \mathrm{~mm}$. The observations are the same like by specimens with plate thickness of $20 \mathrm{~mm}$. The bolt-row $\mathrm{C}$ becomes tension at approximately $210 \mathrm{kNm}$ load level. After this load level is a higher slope in the diagrams to see, the prying effect evolves. At about $290 \mathrm{kNm}$ load level the prying effect stops.

The test specimen BP24_4 slipped on the pinned support which effect is in Figure 22 to see.

Tab. 3. Sum of pre-tension forces of the bolt-rows A and B

\begin{tabular}{cccc}
\hline specimen ID & BP20_0 & BP20_1 & BP20_4 \\
\hline$L_{\text {be_test }}[\mathrm{mm}]$ & $0(0 \cdot d)$ & $160(8 \cdot d)$ & $400(20 \cdot d)$ \\
\hline sum of the pre-tension forces $[\mathrm{kN}]$ & 115 & 103 & 88 \\
\hline
\end{tabular}

Table 4 presents the sum of the pre-tension forces of the boltrows A and B of specimens BP24_0, BP24_4 and BP24_7.

Tab. 4. Sum of pre-tension forces of the bolt-rows A and B

\begin{tabular}{cccc}
\hline specimen ID & BP24_0 & BP24_4 & BP24_7 \\
\hline$L_{\text {be_test }}[\mathrm{mm}]$ & $0(0 \cdot d)$ & $400(20 \cdot d)$ & $800(40 \cdot d)$ \\
\hline sum of the pre-tension forces $[\mathrm{kN}]$ & 100 & 102 & 103 \\
\hline
\end{tabular}

Figure 24 shows the moment-displacement diagrams of the specimens. The calculated and observed failure mode was the same - bolt failure. The displacement diagrams prove the higher the anchorage lengths the higher the achieved load bearing capacity of the joint. The explanation of this finings is similar to the observation in chapter 3.3 .

\section{Calculation results}

The load bearing capacity of the joints was calculated according to the standard [1]. The calculation used the component model method with following assumptions:

- the joint type is beam-to-beam joint i.e. the prying force may always develop in failure mode 1 and 2;
- the material quality for plated elements was the actual value - for instance for plate thickness of $16 \mathrm{~mm} f_{\mathrm{y}, 16}=$ $361.3 \mathrm{~N} / \mathrm{mm}^{2}, f_{\mathrm{u}, 16}=551.5 \mathrm{~N} / \mathrm{mm}^{2}$;

- the used bolt quality was $5.6, f_{\mathrm{yb}, 20}=330 \mathrm{~N} / \mathrm{mm}^{2}, f_{\mathrm{ub}, 20}=$ $550 \mathrm{~N} / \mathrm{mm}^{2}$;

- the partial factors are taken into account of 1.0.

The calculated moment resistances are: $M_{\mathrm{j}, \mathrm{Rd}, 16}=209 \mathrm{kNm}$; $M_{\mathrm{j}, \mathrm{Rd}, 20}=237 \mathrm{kNm}$ and $M_{\mathrm{j}, \mathrm{Rd}, 24}=231 \mathrm{kNm}$.

Table 5 summarizes the measured load bearing capacities and the ratio between the test and calculated results. The results in Table 5 shows, the higher the used bolt length are, the higher the load bearing capacity of the joints is. This fact can explain with the observed failure mode. In all tests finally the bolts in boltrow A were broken after large elongations. The higher anchor length served higher bolt elongation also in bolt-row B and C, which allowed to decreasing the stresses from bending in boltrow A. Moreover the longer bolts helped in the redistribution of bolt forces too. This effect can followed on the moment vs. bolt-row force diagrams clearly. The higher anchor length was used the closer were the bolt-row forces in rows A and B.

\section{Conclusions}

In the paper experimental investigation of bolted base-plate joints is presented. Fourteen full scale specimens with three different base-plate thickness and anchor lengths were tested and calculated in the experimental programme.

From these results the typical failure modes and failure processes were specified and presented. The failure modes were influenced by the plate thickness - in combination of the bolt arrangement, material quality of the plate and bolt diameter, bolt quality - and anchorage length.

The study demonstrated how the prying effect evolves when the plate edges closing and how comes to an end when due to the bolt elongation the edges have no contact more. Moreover was pointed out, that the pre-tensioning of the bolts has a positive effect on the joint behaviour. Using higher pre-tensioning level in the bolts the prying effect stops at higher load level therefore decreasing the joint deformation.

\section{Acknowledgement}

The experimental research work was completed with the financial support of Lindab-ASTRON the authors wish to thank for their helpful collaboration. The author is grateful for the financial support of the Bolyai Research Scholarship. 


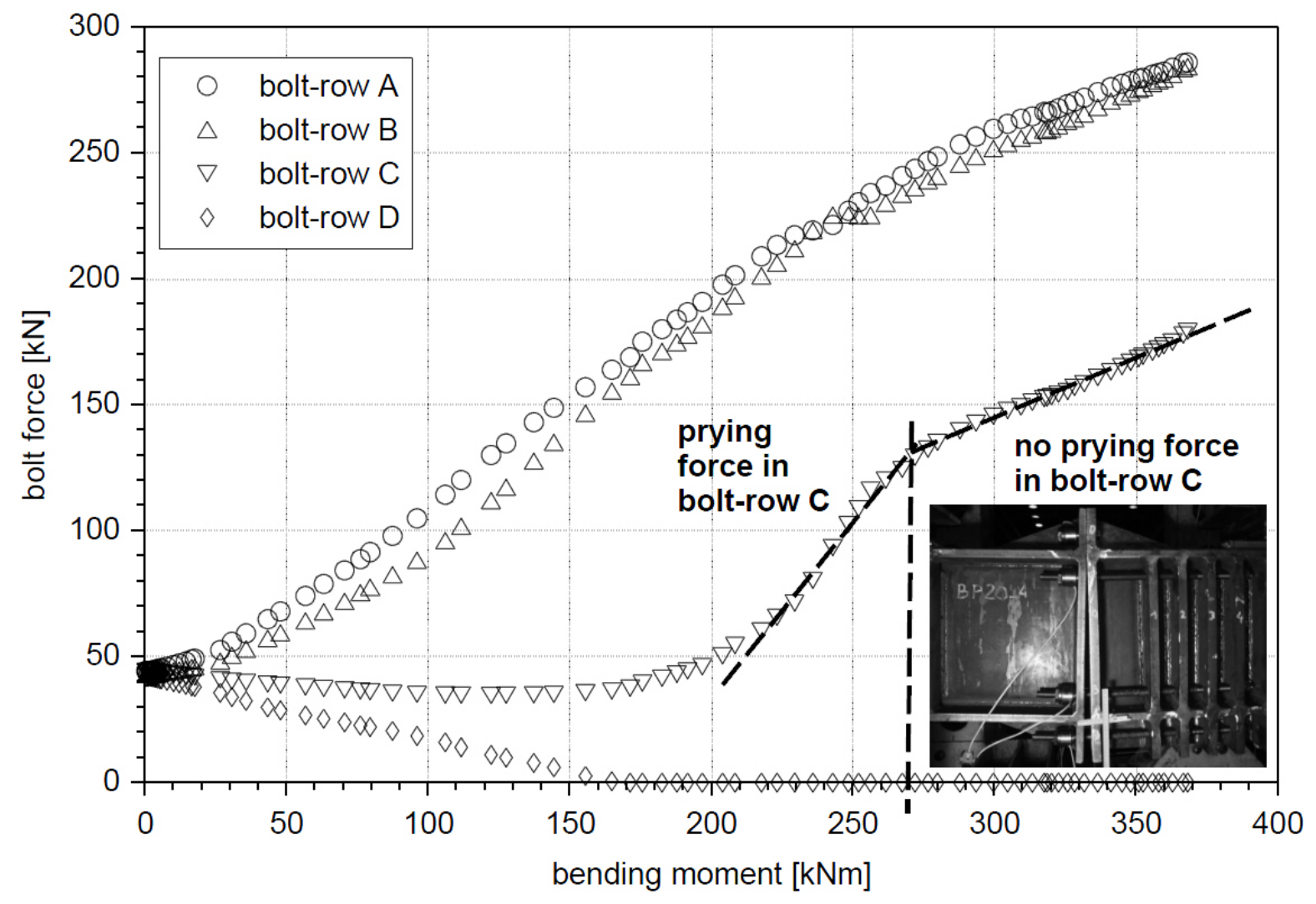

Fig. 19. Moment vs. bolt-row force diagrams $\left(\right.$ BP20_4, $\left.L_{\mathrm{test}, 20 \mathrm{~d}}=400 \mathrm{~mm}\right)$

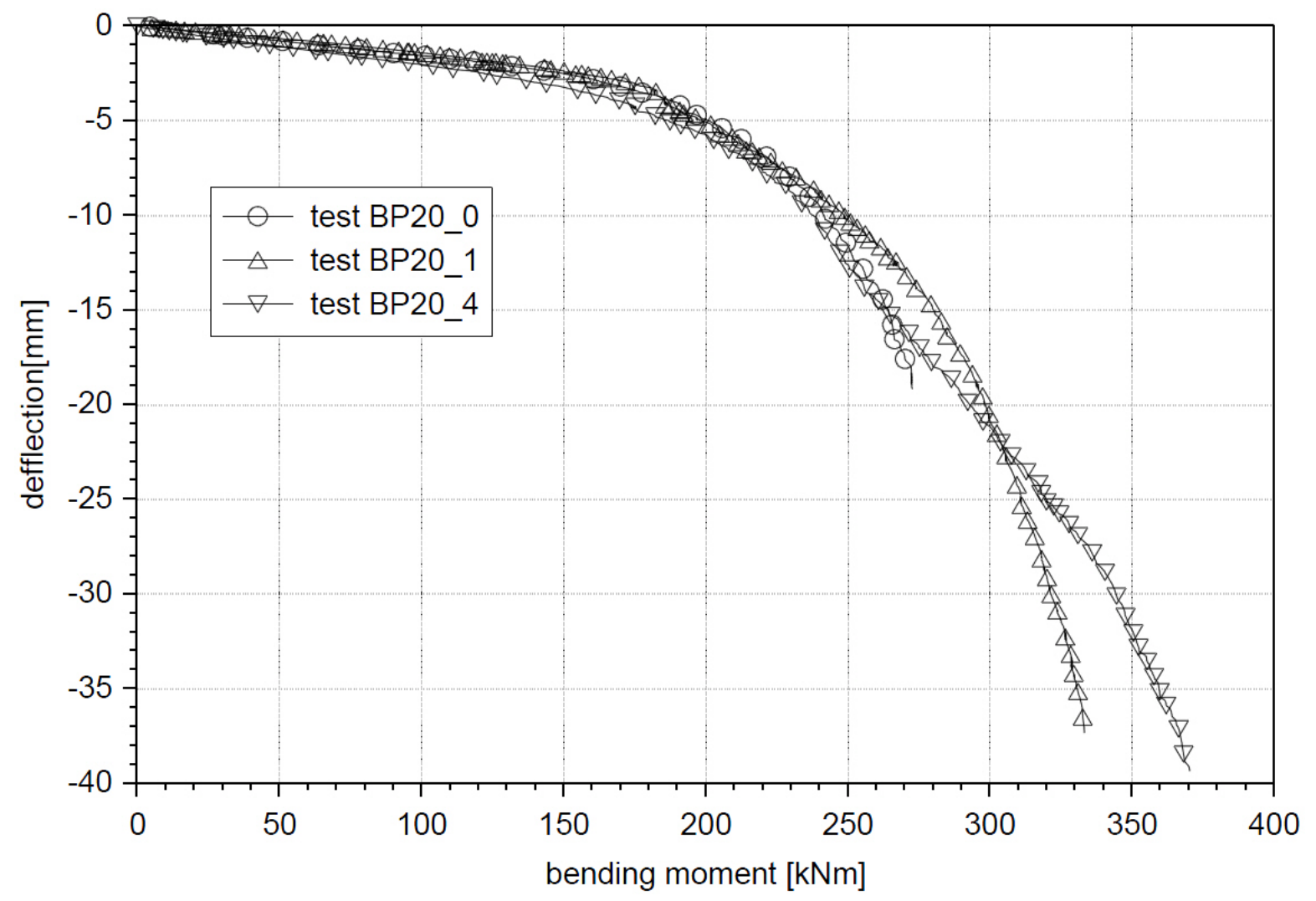

Fig. 20. Moment-displacement diagrams of specimens BP20_0, BP20_1 and BP20_4 


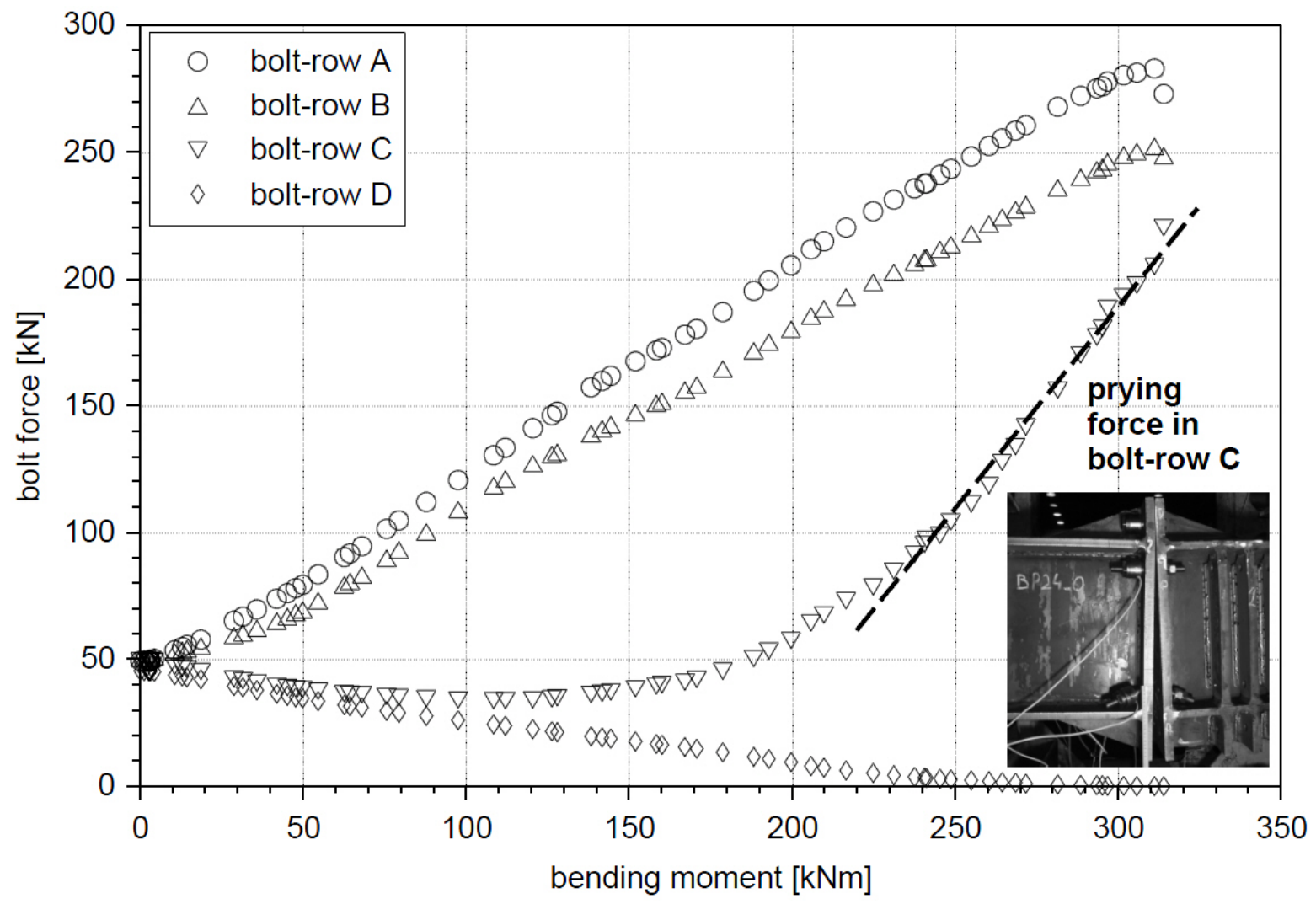

Fig. 21. Moment vs. bolt-row force diagrams BP24_0, $L_{\text {test }, 0 \mathrm{~d}}=0 \mathrm{~mm}$

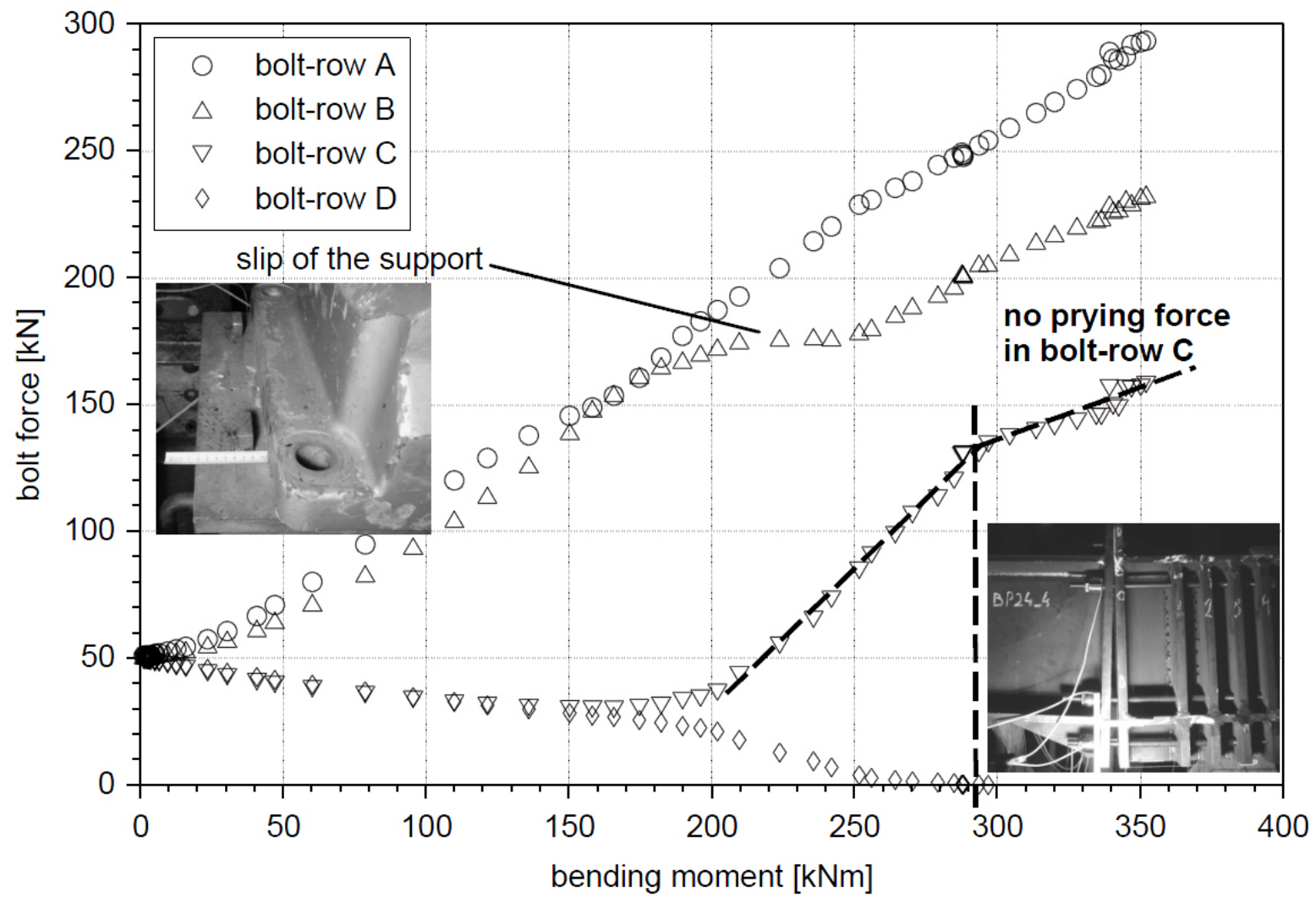

Fig. 22. Moment vs. bolt-row force diagrams $\left(B P 24 \_4, L_{\text {test }, 20 \mathrm{~d}}=400 \mathrm{~mm}\right.$ 


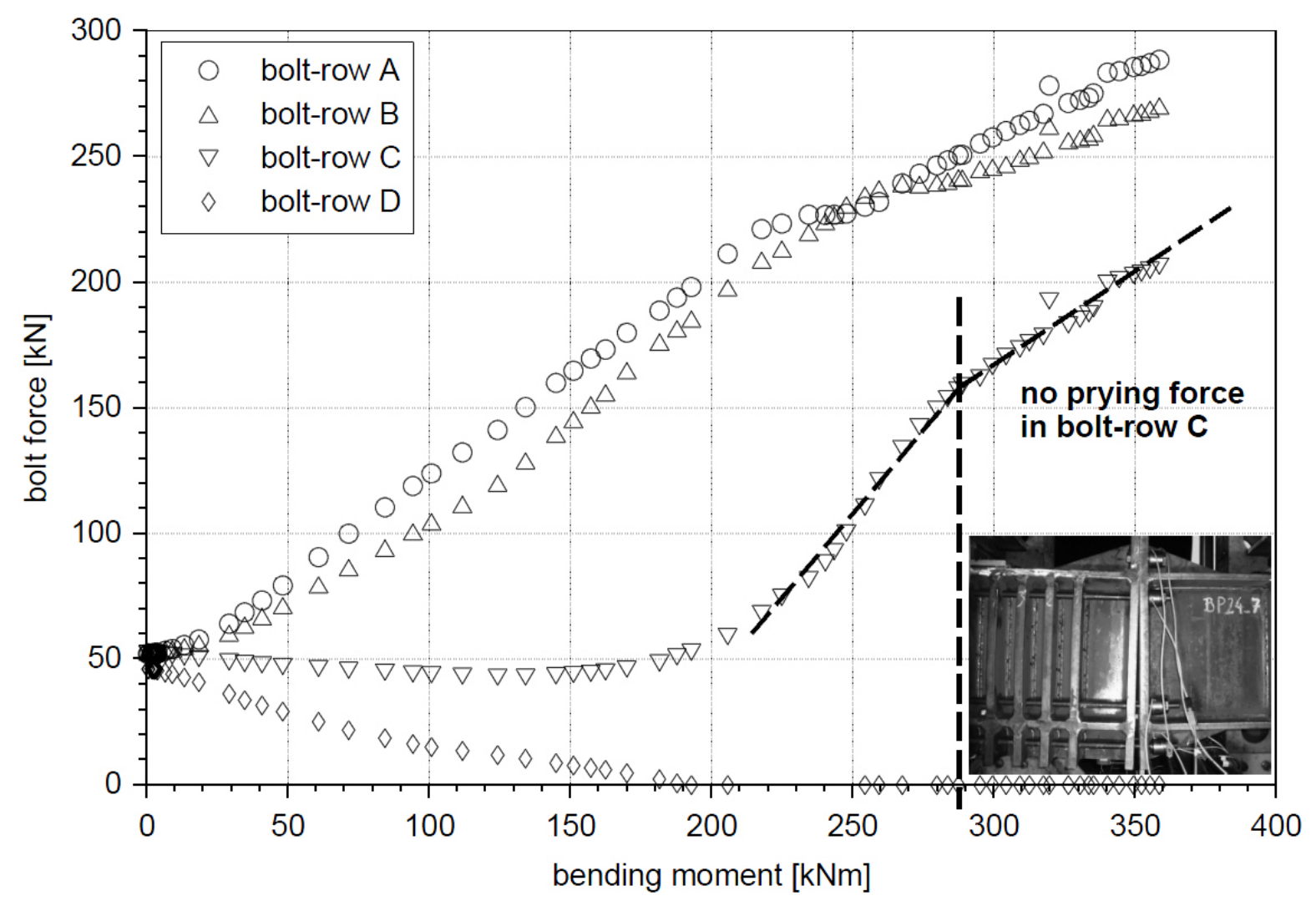

Fig. 23. Moment vs. bolt-row force diagrams (BP24_7, $L_{\text {test }, 40 \mathrm{~d}}=800 \mathrm{~mm}$

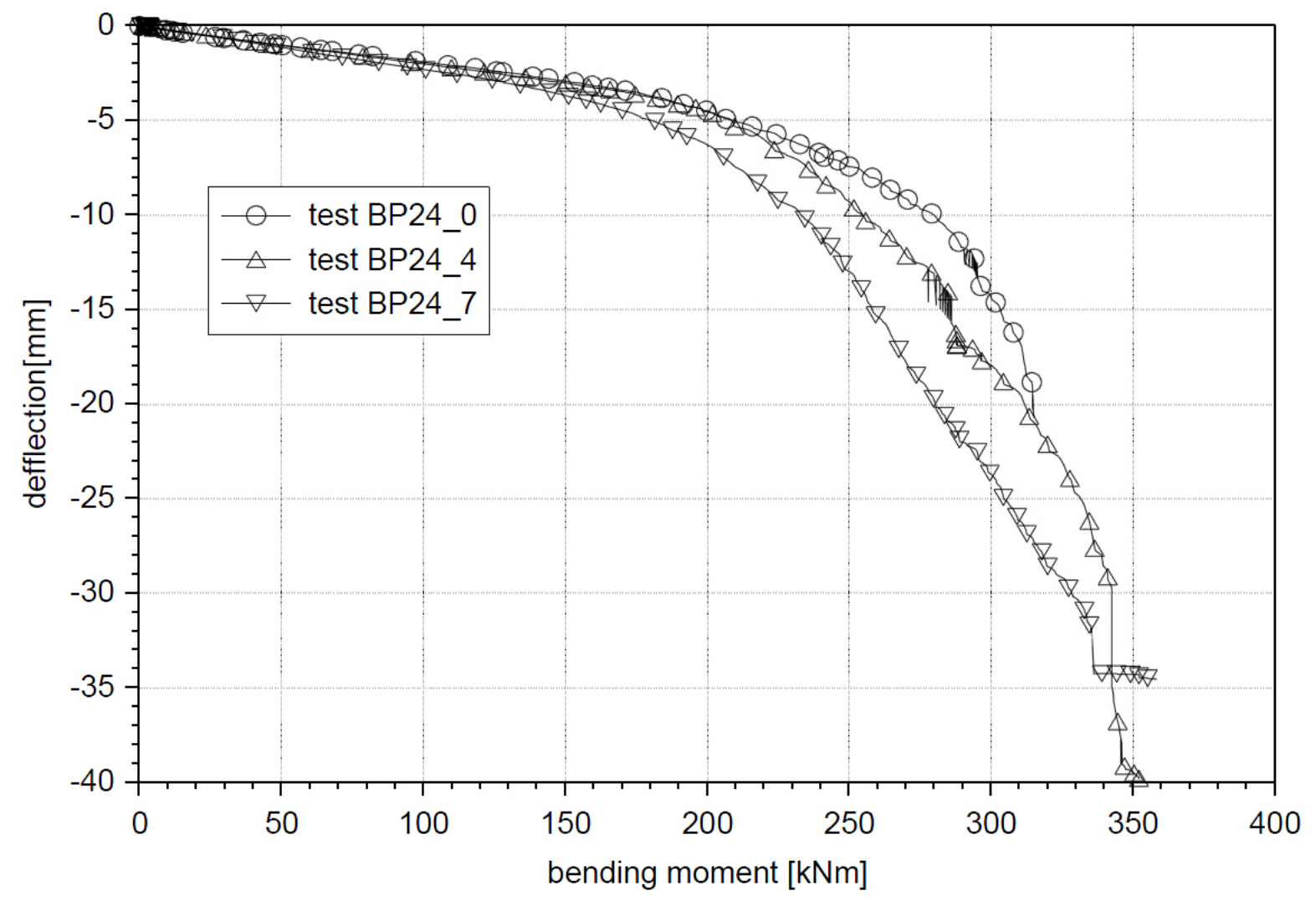

Fig. 24. Moment-displacement diagrams of specimens BP24_0, BP24_4 and BP24_7 
Tab. 5. Measured and calculated load bearing capacities

\begin{tabular}{|c|c|c|c|c|c|c|c|c|c|c|c|c|c|c|}
\hline specimen ID & $\begin{array}{l}0, \\
0^{\prime} \\
\frac{0}{\infty}\end{array}$ & $\begin{array}{l}\bar{c} \\
\overline{0} \\
\bar{n}\end{array}$ & $\begin{array}{l}N_{1} \\
\varphi^{\prime} \\
\frac{\alpha}{\infty}\end{array}$ & $\begin{array}{l}m_{1} \\
\omega^{\prime} \\
\frac{0}{\infty}\end{array}$ & $\begin{array}{l}\dot{\sigma}_{1} \\
0 \\
\frac{0}{\infty}\end{array}$ & $\begin{array}{l}L_{1} \\
\varphi^{\prime} \\
\frac{0}{\infty}\end{array}$ & $\begin{array}{l}\sigma_{1} \\
\omega^{\prime} \\
\frac{\dot{\alpha}}{\infty}\end{array}$ & $\begin{array}{l}\hat{o}^{\prime} \\
\frac{0}{n} \\
\frac{0}{n}\end{array}$ & 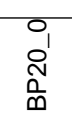 & $\begin{array}{l}\bar{\prime} \\
\text { مे } \\
\frac{N}{\infty}\end{array}$ & $\begin{array}{l}\dot{J}_{1} \\
\text { oे } \\
\frac{\tilde{\alpha}}{\infty}\end{array}$ & 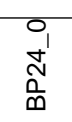 & $\begin{array}{l}\dot{J}_{1} \\
\stackrel{1}{\tilde{N}} \\
\frac{0}{n}\end{array}$ & 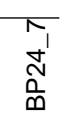 \\
\hline$M_{\text {test }}[\mathrm{kNm}]$ & 314 & 331 & 352 & 340 & 360 & 347 & 352 & 352 & 273 & 333 & 370 & 315 & 352 & 360 \\
\hline$\overline{M_{\mathrm{j}, \mathrm{Rd}} / M_{\text {test }}[\%]}$ & 67 & 63 & 59 & 61 & 58 & 60 & 59 & 59 & 87 & 71 & 64 & 73 & 66 & $\overline{64}$ \\
\hline
\end{tabular}

\section{References}

1 EN 1993-1-8, Eurocode 3: Design of steel structures, Part 1-8: Design of joints, May 2005.

2 Jaspart JP, Recent advances in the field of steel joints - Column bases and further configurations for beam-to-column joints and beam splices, Professorship Thesis, Department MSM Université de Liège, Belgium, 1997.

3 Kuhlmann U, Eligehausen R, Rybinski M, Fichtner S, Design of semirigid steel-to-concrete joints, In: EUROSTEEL 2008 Vol. A, ECCS European Convention for Constructional Steelwork; Graz, Austria, 2008, pp. 423-428.

4 Latour M, Rizzano G, Design of column base connections; Monte Carlo simulation, In: EUROSTEEL 2011 Vol. A, ECCS European Convention for Constructional Steelwork; Budapest, Hungary, 2011, pp. 261-267.

5 Fernezelyi S, Viczián Cs, Classification of column bases; Effect of rotational stiffnes on the load effects of frames, In: EUROSTEEL 2011 Vol. A, ECCS European Convention for Constructional Steelwork; Budapest, Hungary, 2011, pp. 267-272.

6 Lógó J, Rad MM, Knabel J, Tauzowski P, Reliability based design of frames with limited residual strain energy capacity, Periodica PolytechnicaCivil Engineering, 55(1), (2011), 13-20, DOI 10.3311/pp.ci.2011-1.02. 